\title{
Winter climates and coldhardiness in terrestrial insects
}

\author{
William J. TURNOCK and PAUL G. FIELDS*
}

Cereal Research Centre, Agriculture and Agri-Food Canada, 195 Dafoe Rd, Winnipeg, MB, Canada R3T 2M9

Key words. Winter climates, snow-cover, overwintering, terrestrial insects, winter climatic zones, freeze-tolerance, freeze-susceptibility, non-freezing mortality, supercooling point, coldhardiness

\begin{abstract}
Overwintering insects must avoid injury and death from the freezing of tissues and from metabolic disruptions associated with exposure to low, non-freezing temperatures. The winter climates of the world are classified in relation to insect overwintering on the basis of their minimum temperatures and the duration of the winter (when temperatures are below the thermal range for activity and development). Outside the Tropical Wet zone, the severity of exposure to cold (temperature, snowfall, duration of exposure, predictability, variability) can vary from a few days at $0^{\circ} \mathrm{C}$ to months below $-20^{\circ} \mathrm{C}$ with extremes as low as $-60^{\circ} \mathrm{C}$. The severity of the temperature exposure may be ameliorated by the selection by insects of overwintering sites (exposed, partly-exposed, protected). The relationships among overwintering habitats, the minimum winter temperature in climatic zones, and the supercooling points (SCP) of over 350 terrestrial insects from published reports were examined. Variability in the SCP among insects within each climatic zone and habitat was wide. Among the freeze-susceptible species that overwintered in exposed or partly-protected habitats the SCP and the cold severity of climate were correlated. This was not the case for insects that overwintered in protected habitats. The SCP's of freeze-tolerant insects were generally higher than the freeze-susceptible insects, and the SCP's were not tightly linked with the cold severity of climatic zone. Insects, both freeze-susceptible and freeze-tolerant, overwintering in exposed habitats had lower SCP's than insects from habitats that offered some protection from ambient temperatures. Thirty-eight species had reports of SCP's for different geographical locations. Although there were occasionally differences in the SCP's, there was no consistent pattern of insects having lower SCP's when overwintering in colder habitats. The incidence of freeze-tolerance was higher in boreal and polar climatic zones than in climatic zones with warmer winters. Holometabola insects had a higher incidence of freeze-tolerance than hemimetabola insects. Suggestions for future research directions are outlined.
\end{abstract}

\section{INTRODUCTION}

The different types and degrees of coldhardiness in insects are the outcome of adaptations that have enabled insects to live in environments as severe as those in alpine and polar regions. Insects have evolved various developmental and behavioural strategies that mitigate the harmful effects of low temperature (Danks, 1996).

Low temperature damage to insects occurs in two different manners, by injury related to freezing, and by nonfreezing metabolic injury. The formation of ice crystals may cause physical damage, but metabolic injuries unique to the frozen state, such as osmotic stress and anoxia, also affect survival (Storey \& Storey, 1987). Non-freezing metabolic injury is cumulative and can occur at temperatures above the insect's freezing point, but below the threshold for normal metabolism and development. The mechanisms through which these low temperatures may cause injury have not been explained, although several possibilities have been advanced (Storey \& Storey, 1987; Ramløv, 1999).

Insects use two approaches to avoid freezing-related injuries. Freeze-susceptible insects have adapted by lowering their supercooling point (SCP) to avoid freezing, while freeze-tolerant species freeze, but survive freezing through the action of ice-nucleating agents or the removal of ice-nucleators from the system. Most freeze-tolerant species freeze at a relatively high temperature, thereby avoiding injury associated with the rapid formation of large ice crystals. However, such frozen insects may die at a lower temperature (e.g., Vernon et al., 1996). The cause of such mortality is unknown, but could be related either to the metabolic injuries unique to the frozen state (Storey \& Storey, 1987) or to the processes involved in non-freezing injury.

Non-freezing injury is a function of both low temperature and the duration of exposure. The injurious effects accumulate over time, more quickly at lower temperatures (Nedvěd et al., 1998) and can be reversed or repaired if higher temperatures occur before extensive damage has occurred (Turnock \& Bodnaryk, 1993). Adaptations to reduce non-freezing injury include lowering the Upper Limit of the Cold Injury Zone (ULCIZ), and reducing the response to low temperatures and durations of exposure (Turnock et al., 1983, 1998; Nedvěd, 1998; Renault et al., 2002).

Coldhardiness research over the past 50 years has developed an understanding of the impact of freezing on insect tissues and the mechanisms by which freezing injury is avoided. The importance of avoiding injurious low temperatures by behavioural and developmental mechanisms was recognized, and authors have investigated the microclimates of some overwintering habitats (Cloudsley-Thompson, 1962; Danks, 1978; Lamb et al., 1985; Ramløv, 1999; Sinclair, 2001). The SCP has been used in combination with meteorological data to predict

\footnotetext{
* Corresponding author; e-mail: pfields@agr.gc.ca
} 
survival for some species, primarily for those overwintering in exposed habitats (Green, 1962; Sullivan, 1965; Tenow \& Nilssen, 1990; Bale, 1991).

Research on the adaptations used by insects to avoid non-freezing cold injury has received much less attention (Renault et al., 2002). A few studies have attempted to use experimental data on the effect of time and temperature to predict survival (e.g., Lamb et al., 1985; Nedvěd et al., 1998), and some progress has been made in developing techniques for describing the relationship of survival to temperature and duration of exposure (Nedvěd, 1998). Adaptations that affect the ability to survive nonfreezing injury appear to be independent of the adaptations to avoid freezing injury (Turnock et al., 1998).

The SCP is no longer deemed an adequate predictor of overwintering survival for many species (Renault et al., 2002), but a standard method of predicting survival following exposure to conditions causing non-freezing cold injury has not yet been accepted. It is clear, however, that insect species exposed to low temperatures have physiological mechanisms to protect them from both freezing and non-freezing mortality in their overwintering habitats.

Different climates vary in the intensity of the low temperature stress that they place on insects. Potentially freezing temperatures may occur for very short periods (diurnal) or for months. Temperatures potentially causing non-freezing cold injury also may vary from a few hours to many months. One would expect that the level of adaptation to protect the insect from each of these low temperature stresses would be related to the conditions experienced by overwintering insects in their overwintering habitat in the different climatic zones of the world.

As a first step in examining this relationship, we describe the terrestrial winter climates of the world as they affect the level of risk from freezing and from cold injury among overwintering insects in their habitats. We examined three aspects of insect coldhardiness; SCP, freeze tolerance and non-freezing injury. The SCP is the most widely used measure of coldhardiness. Therefore, we examined the relationship between the SCP and climatic zones by habitat for both freeze-susceptible and freeze-tolerant species. We also examined the incidence of freeze-tolerance species among climatic zones and habitats. Other measures of cold tolerance such as the duration of survival at low temperatures, the upper limit of the cold injury zone, the sum of injurious temperatures are better than SCP for predicting survival at low temperatures. However, few studies have been published, so our analysis is limited to ways in which resistance to cold injury varies within and between species. We then pose some questions about insect coldhardiness that need to be answered to advance our knowledge of the processes, and of our ability to predict overwintering survival and the results of climatic changes on overwintering insects.

\section{WINTER CLIMATES AND INSECT OVERWINTERING HABITATS}

Most classifications of the terrestrial climates of the world are based on the Köppen system (Köppen, 1931), which considers both summer and winter climates in establishing five principal groups of world climate. The Köppen system, as modified by Trewartha \& Horn (1980), provides a basis for looking at world climate from the standpoint of an overwintering insect (Table 1). Additional information on the colder climates of the world is found in Grody \& Basist (1996), Bailey et al. (1997), King \& Turner (1997), Brown (2000), and Dye (2002). In this classification of winter climates, we used the major climatic zones of Trewartha \& Horne (1980) - Tropical, Subtropical, Temperate, Boreal, Polar - but we have divided their categories of "Dry Climates" and "Highland Climates" and placed them within the adjacent major zones. The winter climates of dry areas (steppes and deserts) are colder, and the diurnal fluctuations are greater, than in moister areas within the same zone. Climates in highland areas are much more variable than in lowland and dry climates in the same zone. Diurnal temperature fluctuations are greater than at lower altitudes, and the topographic variability affects insolation and wind force, thus increasing variability in the distribution and persistence of snowcover. We also divided the winter climates of the Boreal and Polar zones into "Oceanic" and "Continental" to reflect the effects of open water on the temperature, cloud cover, and precipitation of these areas. The elements of climate affecting insects during winter were selected for the following reasons: (1) the mean air temperature during the coldest month reflects the minimum temperature of exposure; (2) the number of months with mean temperatures below $10^{\circ} \mathrm{C}$ indicates the degree of occurrence of temperatures below the threshold for normal metabolic development of warm-weather insects, and thus the potential mean upper limit of nonfreezing cold injury; (3) the number of months with mean temperatures below $0^{\circ} \mathrm{C}$ indicates the duration of time in colder climates that an insect might be exposed to freezing and non-freezing injurious temperatures; (4) the occurrence and persistence of snowcover greatly affects the temperature in habitats in soil and on the soil surface. Snow may also delay the warming of the overwintering habitat in polar and boreal climates and thus effectively shorten the summer for species overwintering beneath thick snowcover.

The zones of winter climate differ in the degree and duration of stress that they impose on overwintering insects. Insects exposed to air temperatures must avoid death from freezing at temperatures as low as $-50^{\circ} \mathrm{C}$ and survive exposure to temperatures that may cause nonfreezing injury and death for as long as 10 months. However, not all insects overwinter in habitats that are exposed to air temperature, and both the temperature and the duration of exposure to low temperatures in less exposed habitats are modified by topographic and vegetative effects on insolation, insulation, and energy fluxes (Geiger, 1950; Oke, 1987).

The natural overwintering habitats were classed according to their degree of exposure to ambient air temperature as: (1) exposed: overwintering on vegetation (e.g., trees, shrubs) or other structures above the ground 


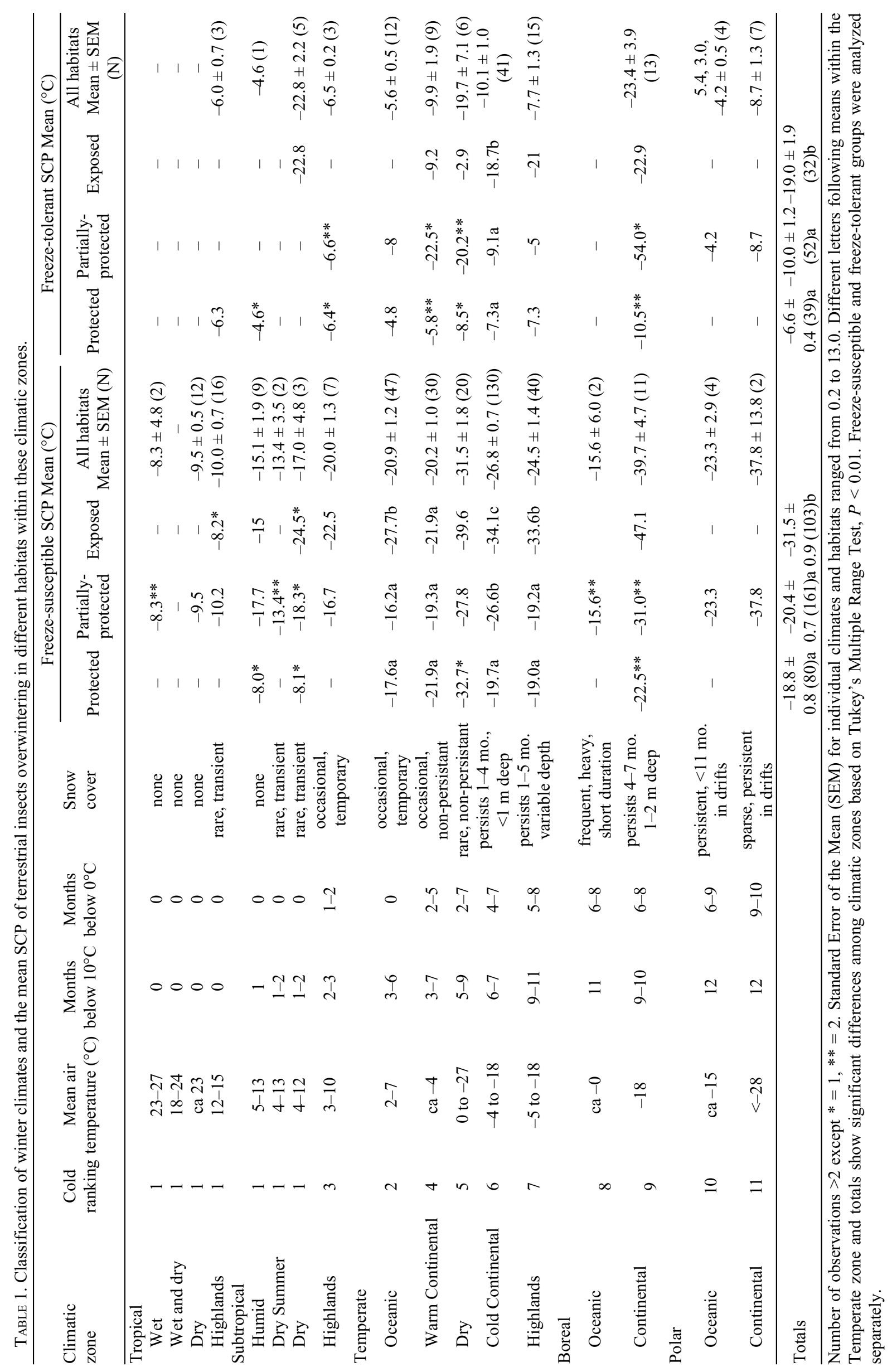


surface and snowcover; (2) partially-protected: overwintering in vegetation or ground surface litter; or (3) protected: overwintering beneath the soil surface. Insects in polar and alpine climates tend to be limited in their overwintering habitats to a narrow, biologically-active, zone between bedrock or permafrost and the top of sparse, low-growing vegetation.

The temperatures in these habitats vary in their relation to air temperatures in different climatic zones as well as varying in response to such variables as snowcover, wind, precipitation, soil type, and vegetation. Of these, snowcover is the major modifier of the temperature of partially-protected and protected habitats. Even small amounts of snow on the foliage of conifers may protect overwintering insects (e.g., Neodiprion sertifer eggs on pine branches in Boreal forests; Sullivan, 1965).

In climatic zones where freezing temperatures are associated with temporary invasions of cold air masses (Subtropical, Temperate Oceanic, Temperate Warm Continental, and Temperate Dry), even non-persistent snowfall can protect insects in partially-protected overwintering habitats. In these areas insects in exposed habitats experience the minimum air temperatures, while those in protected habitats are buffered. Partially-protected habitats can be protected from extremes of low temperature if invasions of cold air are accompanied by snow.

In climatic zones with persistent, deep snowcover, all habitats beneath the snow are protected from the fluctuations of air temperatures. With sufficient snowcover, insects overwintering in the litter, or on soil surfaces can be considered to occupy protected habitats. Although the depth and insulation properties of snowcover vary within the Temperate Cold Continental and Boreal zones, an insulating blanket of snow can maintain soil temperatures at levels similar to those in the Temperate Warm Continental zone, where snowcover does not persist.

The climatic zones and overwintering habitats can be grouped on the basis of their temperatures and duration of exposure (Table 1).

\section{Tropical Climates}

There is no winter, and only in the Highlands do diurnal temperatures fall below $0^{\circ} \mathrm{C}$. Minimum temperatures decrease with altitude, and may be as low as $-20^{\circ} \mathrm{C}$ at altitudes above $3000 \mathrm{~m}$. Temperatures in the Tropical Wet and Wet and Dry climates are rarely below $10^{\circ} \mathrm{C}$ and do not impose any low temperature stress on insects. Diurnal frosts in Tropical Dry climates are mild with short durations, and both air and soil temperatures rise rapidly during the day. Insects need some protection from freezing, but the duration of temperatures below $10^{\circ} \mathrm{C}$ seems too short to cause non-freezing injury.

\section{Subtropical Climates}

Winters are short and mean air temperatures are below $10^{\circ} \mathrm{C}$ for $1-3$ months. Cold air masses bring occasional brief periods of freezing air temperatures, rarely accompanied by snow. Insects in exposed habitats need some resistance to freezing, and all habitats have short periods of temperatures that could cause cold injury. Subtropical
Humid and Dry Summer climates do not expose insects to severe stress from either freezing or non-freezing injury, regardless of their overwintering habitat. Insects in Subtropical, Humid, and Dry climates are exposed to some diurnal freezing during occasional short periods of freezing weather associated with invasions of cold air. Snow is rare and transient, providing no insulation.

\section{Temperate Climates}

There is a definite winter season during which air temperatures are below $10^{\circ} \mathrm{C}$ and, in all but the Oceanic zone, below $0^{\circ} \mathrm{C}$ for $3-8$ months. The depth and persistence of snowcover is a factor modifying the impact of air temperatures in the soil and on the ground surface. Where snowcover is not persistent, insects overwintering on vegetation or on the soil surface are exposed to the fluctuating temperatures, similar to air temperatures, that are associated with invasions of warm and cold air masses. The variability in the severity of the minimum temperature and the duration of exposure to low temperatures among the habitats and sub-zones in the Temperate zone is greater than in other zones. Therefore the level of adaptations to avoid freezing and non-freezing injury also should be more variable than in other zones.

The Temperate Oceanic and Warm Continental climates do not expose overwintering insects to very low minimum temperatures, but potentially injurious nonfreezing temperatures may persist for 3-6 months. Insects overwintering in exposed and partially-protected habitats may be exposed to temperatures fluctuating above and below the ULCIZ due to alternating invasions of polar and subtropical air masses. Such insects may be adapted to repair injuries in warmer weather following cold periods (Casagrande \& Haynes, 1976; Nedvěd et al., 1998). Snowcover may temporarily protect insects on the soil surface from low minimum temperatures.

The winters in the Dry climates are colder and drier, and all the overwintering habitats have lower temperatures than those in the Oceanic and Warm Continental climates. Snowfalls are light and do not persist for long periods. Winter air temperatures in Temperate Cold Continental climates are well below $-10^{\circ} \mathrm{C}$, and freezing temperatures persist for 4-7 months. Where snowfall is heavy and persistent, temperatures on and in the soil are much warmer than the air temperatures, and generally remain above $-10^{\circ} \mathrm{C}$.

\section{Boreal Climates}

The winters are long and cold. The short winter days and limited solar heating reduce diurnal fluctuations. Polar air masses with low temperatures are dominant. Snowfall is moderate to heavy and persists (French \& Slaymaker, 1993). Surrounding waters in Boreal Oceanic zones ameliorate the severity of polar air masses so that mean air temperatures remain close to $0^{\circ} \mathrm{C}$. There is little variability in daily and seasonal temperatures, and freezing may occur throughout the year (Klok \& Chown, 1997). Snowfalls may be heavy but usually are soon melted by rains. In contrast, Boreal Continental climates often have minimum air temperatures below $-40^{\circ} \mathrm{C}$, but 
surface and soil temperatures usually remain above $-15^{\circ} \mathrm{C}$ because snow is persistent and usually heavy enough to protect these habitats from air temperature fluctuations.

\section{Polar Climates}

The winters are long and days are very short so that diurnal fluctuations of air temperatures are small. Snowfall is generally light (a very cold desert), and high winds keep some areas snow free, while forming drifts in other areas. Permafrost limits overwintering habitats in the soil, and the areas in which snowdrifts normally form may not be utilized by overwintering insects because slow melting of the snow in the spring shortens the already critically short summer (Danks et al., 1994). Islands in the Arctic and those close to the Antarctic continent that are surrounded by sea-fast ice in the winter do not differ from Polar Continental areas during this season (King \& Turner, 1997). Antarctic islands with Polar Oceanic climates have little variability in daily or seasonal temperatures, and freezing temperatures can occur throughout the year. The tundra climates of the Northern hemisphere have air temperatures below $-50^{\circ} \mathrm{C}$, and overwintering insects need to be well-protected against both freezing and non-freezing injury.

\section{Highland Climates}

These climates are difficult to characterize because the zonal climate is modified by differences caused by altitudinal variability, degree of exposure to prevailing wind patterns, sparse vegetation, shallow soils above rock, and variable snowcover. Diurnal frosts in Tropical Highlands are mild and of short duration. Insectan habitats warm rapidly during the day. Some resistance to freezing and non-freezing injury is needed. In Subtropical Highlands, diurnal freezing temperatures occur more frequently and are lower than in the Tropical Highlands, but temperatures rise quickly under strong insolation. Occasional snows do not persist at altitudes occupied by insects. Mean monthly temperatures below the activity threshold occur for 2-3 months, so resistance to both types of injury are needed by overwintering insects. Temperatures in the Temperate Highlands are colder than in lower areas at the same latitude. Snowfall is variable and persists in some habitats. Freezing temperatures occur for 5-8 months, and overwintering insects need resistance to freezing and non-freezing injury. Temperate Highlands that are influenced by air masses from oceans combine diurnal freeze/thaw cycles with longer cold periods (Ramløv, 1999; Sinclair, 2001; Sinclair et al., 2003). In such habitats, the ability to survive frequent exposures to freezing temperatures must be combined with resistance to, or repair of, cold injury and the rapid reactivation of metabolic processes as temperatures rise.

\section{WINTER CLIMATES AND INSECT FREEZING}

The extensive literature on the SCP of insects was examined to determine if there is a relationship between the SCP and winter temperatures. From each report, the species, strategy (freeze-susceptible or freeze-tolerant), stage of development, overwintering habitat, location, and
SCP were extracted and the climatic zone of the location was determined. In most cases the original publications were examined, but information on some species was extracted from review articles such as CloudsleyThompson (1970), Lozina-Lozinskii (1974), Merivee (1978), and Sømme (1982). References for individual species are not cited, except for species that are discussed. Sources of error in these records include the use of different techniques in measuring the SCP and the lack of precise information on overwintering habitats. This data base is limited to terrestrial insects in their natural habitats, and it is available from the authors. The considerable literature on insects in glasshouses and grain bulks, and on Collembola and Arachnida was not considered.

The information on freezing-susceptible (338 records for 268 species) and freezing-tolerant (120 records for 94 species) insects was analysed separately. Preliminary analyses of the SCPs of Hemimetabola and Holometabola showed a similar relationship to climate and habitat, so they were combined in the analyses. The distribution of records does not cover all the climatic zones and habitats, and several have only a few records.

\section{Variations Among Species by Climatic Zones}

The SCP of overwintering insects was related to the severity of the winter temperatures, although variability was high both within and among climatic zones and habitats (Fig. 1). Correlation analyses were conducted for both freeze-susceptible and freeze-tolerant species between the ranking of the severity of the winter temperature (Table 1) and the SCPs in each climatic zone and habitat with sufficient records (Fig. 1). The correlation was significant among freeze-susceptible insects in exposed and partially-protected habitats, but not in protected habitats. For freeze-tolerant insects there was no correlation between SCP and cold severity in exposed and partially-protected habits. There was a correlation in protected habitats, but the range of SCP values was narrow.

The mean SCP of both freeze-susceptible and freezetolerant insects overwintering in exposed habitats was significantly lower than in the other habitats (Table 1). For freeze-susceptible insects, this difference among habitats did not occur in the Tropical zone or in the warmer climates (Humid, Dry Summer) of the Subtropical zone. For freeze-tolerant species, a significant difference between the exposed and the other habitats occurred only in two of the climates with the lowest winter temperatures, the Temperate Highland and Boreal Continental climates.

In Tropical Climates, the mean SCP of freezesusceptible insects ranged from -8.2 to $-10.2^{\circ} \mathrm{C}$ (Table 1). The SCPs for individual species were all above $-13.0^{\circ} \mathrm{C}$, except for two species from the Tropical Highlands: Cossonus frigidus Schiødte $\left(-17.5^{\circ} \mathrm{C}\right)$ and Brachycaudus helichrysi (Kaltenbach) $\left(-25.1^{\circ} \mathrm{C}\right)$ (Sømme \& Zachariassen, 1981). Both of these species are normally exposed to lower night temperatures than the other 14 species reported by these authors from high altitudes on Mount Kenya, $C$. frigidus because it inhabits dry rather than wet plant material, and $B$. helichrysi because it was 


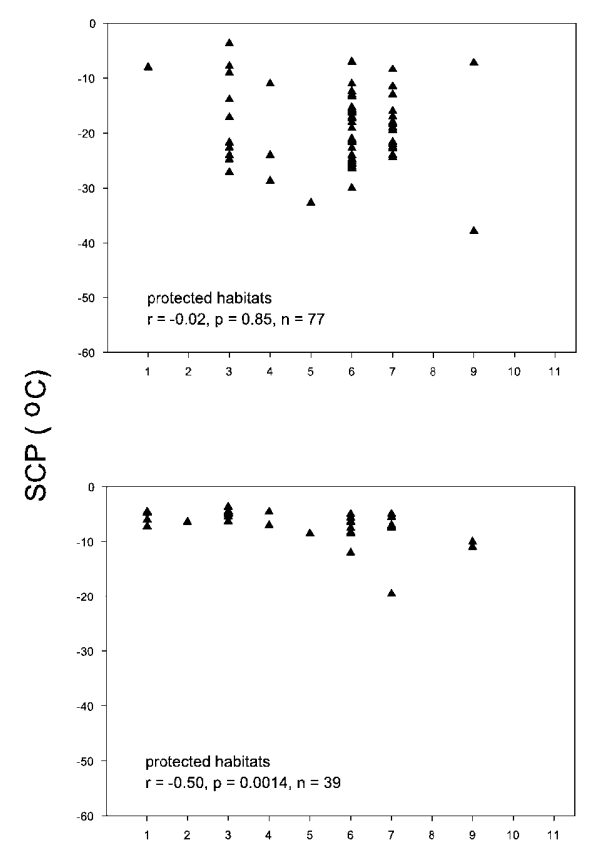

Freeze-Susceptible Insects

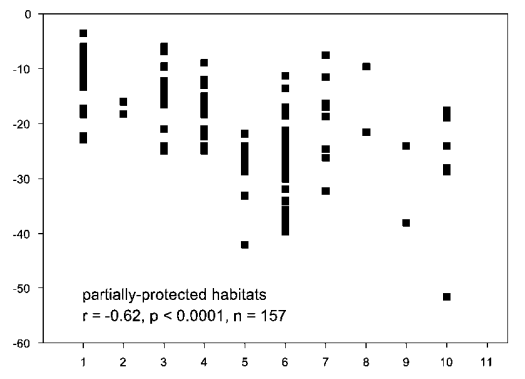

Freeze-Tolerant Insects
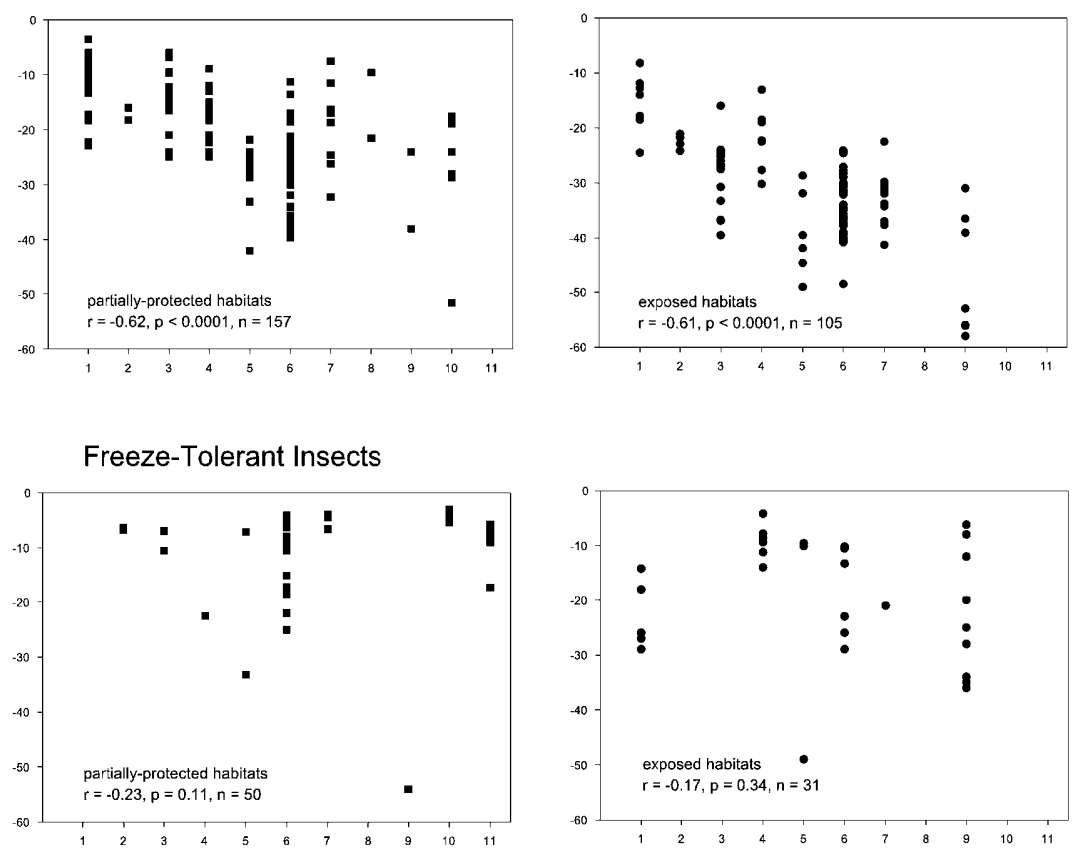

Ranking Cold Severity of Habitats

Fig. 1. The variation in SCP of freeze-susceptible and freeze-tolerant insects, grouped by habitat (Table 1) and ranked by cold severity. A Spearman Rank Order Correlation was conducted for each data set.

collected from the highest altitude sampled, $4985 \mathrm{~m}$, where night temperatures are likely below $-20^{\circ} \mathrm{C}$. The SCPs of three species of freeze-tolerant insects from exposed Highland habitats ranged from -4.8 to $-7.3^{\circ} \mathrm{C}$.

In Subtropical Climates, the SCPs of freeze-susceptible species was high $\left(-8.1,-8.0^{\circ} \mathrm{C}\right)$ in protected habitats, lower $\left(-13.0\right.$ to $\left.-18.0^{\circ} \mathrm{C}\right)$ in partially-protected habitats, and lowest (below $-20.0^{\circ} \mathrm{C}$ ) in exposed habitats of the Dry and Highlands zones (Table 1). The lowest SCP in the Humid and Dry Summer zones was for Helicoverpa (Heliothis) zea (Boddie), the cosmopolitan pest of maize (Roberts et al., 1972). Most of the freeze-tolerant species had high SCPs $\left(-4.6\right.$ to $\left.-6.6^{\circ} \mathrm{C}\right)$, but three species from the subtropical dry zones had SCPs from -26.0 to $-29.0^{\circ} \mathrm{C}$, Eurytoma obtusiventris Gahan, Eurytoma gigantea Walsh, and Mordellistena unicolor Leconte. These species inhabit goldenrod galls and have a wide distribution in more northerly climates (Baust et al., 1979; Duman \& Montgomery, 1991).

In Temperate Climates, freeze-susceptible insects show increasingly lower SCPs from protected, through partially-protected, to exposed habitats (Table 1). The mean SCP in exposed habitats was significantly lower than in the other habitats in the Oceanic, Cold Continental, and Highlands zones. Only in the Cold Continental zone was the mean SCP in the partially-protected habitat significantly lower than in the protected habitat.

The SCPs of freeze-tolerant insects in all Temperate zones were mainly above $-15^{\circ} \mathrm{C}(86 \%, N=82)$. The 10 species with SCPs below $-15^{\circ} \mathrm{C}$ included the three species from goldenrod galls (Baust et al., 1979) that are also found in the Subtropical Dry zone (see above); Ostrinia nubilalis (Hubn.) in the Temperate Oceanic, Warm Continental, and Cold Continental zones (Barnes \& Hodson, 1956; Hanec \& Beck, 1960; Grubor-Lajsic et al., 1991), Bracon cephi (Gahan) a parasitoid of the wheat stem sawfly, Cephus cinctus Nort. (Salt, 1959), and Macdunnoughis confusa Stph. (Merivee, 1978). All of these have widespread distributions and overwinter in habitats where snowcover is minimal, either in open grasslands or in crop residues on the soil surface. The mean SCP of species in exposed habitats of the Cold Continental zone was significantly lower than in the other habitats.

In Boreal Climates, the mean SCP of freeze-susceptible species was higher in the Oceanic than Continental zones (Table 1). In the Continental zone, the mean SCP decreased from $-22.7^{\circ} \mathrm{C}$ in protected habitats, to $-31.0^{\circ} \mathrm{C}$ in partially-protected habitats, to $-47.1^{\circ} \mathrm{C}$ in exposed habitats. The first two habitat types are protected from low air temperatures by a cover of snow that is generally deep and persistent. Insects in these habitats have only slightly lower SCPs than insects overwintering in similar habitats in the Temperate Cold Continental zone. Among nine species from partially-protected and exposed habitats, only one, Rheumaptera hastata (L.), had a SCP (ca $-24.0^{\circ} \mathrm{C}$; Werner, 1978) higher than $-31.0^{\circ} \mathrm{C}$, and the others had SCPs from -31.0 to $-58.0^{\circ} \mathrm{C}$. The 10 freezetolerant species from exposed habitats (SCPs -6.2 to $-36.0^{\circ} \mathrm{C}$ ) were all collected under dead or loose bark in the interior of Alaska, USA, above the deep and persistent snowcover (Werner, 1978). In protected habitats in the same location, Pterostichus brevicornis Kirby had a 
SCP of $-11^{\circ} \mathrm{C}$. In partially-protected habitats in the Rocky Mountains, the SCP of Pytho planus (deplanatus) Olivier was $-54.0^{\circ} \mathrm{C}$ (Ring, 1982).

In Polar Continental Climates, where air temperatures are very low, snowfall light, and winds strong, most insects overwinter in partially-protected habitats. The SCPs of two freeze-susceptible species from Arctic Canada were -24.0 and $-51.6^{\circ} \mathrm{C}$ (Ring \& Tesar, 1980; Ring, 1982), while those of seven freeze-tolerant species ranged from -6.0 to $-17.3^{\circ} \mathrm{C}$. Polar Oceanic climates are less severe. Among species from Antarctic islands, the SCPs of freeze-tolerant species were -3.0 and $-5.4^{\circ} \mathrm{C}(N$ $=2$ ), and of freeze-susceptible species from -18.9 to $-28.7^{\circ} \mathrm{C}(N=3)$.

\section{Variation Within Species Among and Within Climatic Zones}

The mean SCP for a species has been reported for more than one population within a climatic zone or from populations from more than one climatic zone for 25 species of freeze-susceptible (Table 2) and 13 species of freezetolerant insects (Table 3). The mean SCP reported from these studies may be influenced by the source of the material, small sample size, and differences in technique in determining the freezing point. The degree to which such influences have affected the mean SCP cannot be determined from the published information. We accepted that SCPs differing by $4^{\circ} \mathrm{C}$ or more were evidence of a real difference among species or populations.

Among the 24 freeze-susceptible species for which records from more than one location within a climatic zone were available (Table 2), the difference was less than $4^{\circ} \mathrm{C}$ for 9 species in 12 climatic zones. Their mean within-zone difference in SCP records was $1.4^{\circ} \mathrm{C}$. Although there were occasionally differences in the SCP's, there was no consistent pattern of insects having lower SCP's overwintering in colder habitats.

The difference of $4.0^{\circ} \mathrm{C}$ between populations of Rhopobota naevana (Hübner) in western (warmer) and eastern (colder) parts of southern Norway (Temperate Cold Continental zone) is consistent with differences in winter temperatures (Sømme, 1965). There are large differences among populations of Neodiprion sertifer Geoffr. within the Temperate Cold Continental climate of Estonia and Latvia, $-34.1^{\circ} \mathrm{C}$ (Sullivan, 1965 ); -39.1 to $-40.6^{\circ} \mathrm{C}$ (Kopvillem \& Kuusik, 1971; Merivee, 1978) but not among populations in Japan and Canada $\left(-30.8^{\circ}\right.$ and $-32.1^{\circ} \mathrm{C}$ ) or between those and populations in the Temperate Highlands of Europe $\left(-30.1\right.$ to $\left.-32.0^{\circ} \mathrm{C}\right)$ (Sullivan, 1965). Similar differences occur between populations of D. radicum from Estonia $\left(-25.2^{\circ} \mathrm{C}\right.$; Merivee, 1978) and Leningrad (ca $-21^{\circ} \mathrm{C}$; Koštál, 1993) but Turnock et al. (1998) found no relationship between the SCP and the mean January air temperature for populations of this species from different locations and climatic zones. Differences within climatic zones in the SCPs of these two species are probably related to the experimental techniques of different researchers, but the difference of $10^{\circ} \mathrm{C}$ between reports for Dendroides canadensis Latreille, by the same researchers (Duman, 1980; Olsen \& Duman, 1997) cannot be explained.

Among 16 freeze-susceptible species that were examined from more than one climatic zone, 5 have SCPs that differ among zones (Table 2). In Canada, the fall cankerworm, Alsophila pometaria (Harris), has a lower SCP in the Temperate Dry climate of Alberta $\left(-44.6^{\circ} \mathrm{C}\right.$; Sømme, 1964), than in the Temperate Cold Continental climate of Nova Scotia $\left(-37.2^{\circ} \mathrm{C}\right.$; MacPhee, 1964). The SCP of Neodiprion pratti banksianae Rohwer in Canada is higher in the Temperate Cold Continental zone $\left(-34.0^{\circ} \mathrm{C}\right)$ than that in the colder Boreal Continental zone $\left(-39.1^{\circ} \mathrm{C}\right)$ (Sullivan, 1965). The European elm bark beetle, Scolytus multistriatus (Marsham), freezes at a higher temperature in the Temperate Cold Continental climate of Michigan, USA, $\left(-24.1^{\circ} \mathrm{C}\right.$; Truchan \& Butcher, 1970) than in the colder Boreal Continental zone of mid-Asia $\left(-53.0^{\circ} \mathrm{C}\right.$; Lozina-Lozinskii, 1974). Differences in the SCP that are correlated with differences in the mean January temperature are also recorded for Pyrrhocoris apterus (L.) in Bulgaria and the Czech Republic (Kalushkov \& Nedvěd, 2000; Hodková \& Hodek, 1994). Exochomus quadripustulatus (L.) is anomalous, with an SCP of $-13.5^{\circ} \mathrm{C}$ in the Temperate Cold Continental zone at Leningrad (Pantyukhov, 1971) and $-24.0^{\circ} \mathrm{C}$ from the Temperate Warm Continental zone in southern Bohemia (Nedvěd, 1993).

The SCP of most freeze-susceptible species does not vary greatly within their range of occurrence, but four species show a variation in their SCP that is correlated with temperature differences both within and among climatic zones (Table 2). Three of the four species overwinter on the twigs, branches, or bark of trees in the colder Temperate zones, while the fourth overwinters in litter in the Subtropical Dry and Temperate Warm Continental zones.

Variation within or among climatic zones in the SCP of freeze-tolerant species was generally small (Table 3 ). The distribution of insect species inhabiting the galls of goldenrod in North America includes several climatic zones. The SCPs of populations of goldenrod gall fly, Eurosta solidaginis in the Suptropical Dry climate of Texas varied from -10.0 to $-18.2^{\circ} \mathrm{C}$ (Baust et al., 1979), but populations in the Temperate Cold Continental and Temperate Dry zones only varied from -9.6 to $-13.7^{\circ} \mathrm{C}$ (Sømme, 1964, 1978; Baust et al., 1979; Baust \& Lee, 1981; Rickards et al., 1987). The SCP of another species in goldenrod galls, E. gigantea, varied from $23.0^{\circ} \mathrm{C}$ (Temperate Cold Continental climate, cold with heavy snow fall), $-27.0^{\circ} \mathrm{C}$ (Subtropical Dry climate, rarely cold and little snow), to $-49^{\circ} \mathrm{C}$ (Temperate Dry climate, cold, little snow, Brown, 2000). The SCPs of another widespread species, the European corn borer, O. nubilalis, differed among the Temperate Warm Continental climate of Yugoslavia $\left(-22.5^{\circ} \mathrm{C}\right.$, Grubor-Lajsic et al., 1991) and the Temperate Cold Continental climate of St. Petersburg, Russia $\left(-25.0^{\circ} \mathrm{C}\right.$, Lozina-Lozinskii, 1974), Minnesota, USA $\left(-22.0^{\circ} \mathrm{C}\right)$ and Wisconsin USA $\left(-18.6^{\circ} \mathrm{C}\right.$, Barnes \& Hodson, 1956; Hanec \& Beck, 1960). 
TABLE 2. Comparison of the SCP of freeze-susceptible insects within and among winter climates.

\begin{tabular}{|c|c|c|c|c|}
\hline Species & Climate & Location & $\mathrm{SCP}\left({ }^{\circ} \mathrm{C}\right)$ & Reference \\
\hline Hippodamia convergens & Subtropical Highlands & CA USA & $-16.0,-18.2$ & Lee, 1980; Bennet \& Lee, 1989 \\
\hline Myzus persicae & Temperate Oceanic & $\begin{array}{l}\text { Leeds UK } \\
\text { Wales UK }\end{array}$ & $\begin{array}{l}-27.5 \\
-26.6 \\
\end{array}$ & $\begin{array}{c}\text { O'Doherty \& Bale, } 1985 ; \\
\text { Bale et al., } 1988 \\
\end{array}$ \\
\hline Dendroides canadensis & Temperate Warm Continental & IN USA & $-12.0,-22.0$ & Duman, 1980; Olsen \& Duman, 1997 \\
\hline $\begin{array}{l}\text { Rhopobota } \\
\text { (Acrolita) naevana }\end{array}$ & Temperate Cold Continental & Norway & $-26.0,-30.0$ & Sømme, 1965 \\
\hline Amphipoea fucasa & Temperate Cold Continental & $\begin{array}{c}\text { Japan } \\
\text { Estonia }\end{array}$ & $\begin{array}{l}-36.2 \\
-35.7 \\
\end{array}$ & $\begin{array}{c}\text { Tsutsui et al., } 1987 \\
\text { Merivee, } 1978\end{array}$ \\
\hline $\begin{array}{l}\text { Leguminivora } \\
\text { glycinivorella }\end{array}$ & Temperate Cold Continental & Japan & $-24.0,-24.9$ & $\begin{array}{c}\text { Shimada et al., 1984; } \\
\text { Sakagami et al., } 1985 \\
\end{array}$ \\
\hline Ips acuminatus & Temperate Highlands & Norway & $-33.8,-34.3$ & Gehrken 1984; Satvedt, 1975 \\
\hline Rhagium inquisitor & Temperate Highlands & Norway & $\begin{array}{l}-17.0,-19.0 \\
-27.9\end{array}$ & $\begin{array}{c}\text { Zachariassen \& Hammel, 1976; } \\
\text { Zachariassen, 1980; Gehrken, } 1992\end{array}$ \\
\hline Locusta migratoria & $\begin{array}{c}\text { Tropical Wet } \\
\text { Subtropical Humid } \\
\text { Temperate Warm Continental } \\
\text { Temperate Warm Continental }\end{array}$ & $\begin{array}{l}\text { Hainan China } \\
\text { Anhui China } \\
\text { Hebei China } \\
\text { Liaoning China }\end{array}$ & $\begin{array}{l}-23.7 \\
-25.5 \\
-25.2 \\
-23.6 \\
\end{array}$ & Jing \& Kang, 2003 \\
\hline Psacothea hilaris & $\begin{array}{c}\text { Tropical Wet } \\
\text { Subtropical Humid } \\
\text { Temperate Warm Continental }\end{array}$ & $\begin{array}{l}\text { Ishigaki Japan } \\
\text { South Japan } \\
\text { Akita Japan }\end{array}$ & $\begin{array}{c}-38.0 \\
-27.0,-27.3 \\
-27.4\end{array}$ & Shintani \& Ishikawa, 1999 \\
\hline Pieris brassicae & $\begin{array}{c}\text { Temperate Oceanic } \\
\text { Temperate Oceanic } \\
\text { Temperate Cold Continental }\end{array}$ & $\begin{array}{l}\text { Norway } \\
\text { Leeds UK } \\
\text { Estonia }\end{array}$ & $\begin{array}{l}-25.8,-25.0 \\
-23.9 \\
-26.4,-25.5\end{array}$ & $\begin{array}{c}\text { Sømme, 1967; Pullin et al., 1991; } \\
\text { Pullin \& Bale, 1989; Hansen \& Merivee, } \\
\text { 1971; Merivee, } 1978\end{array}$ \\
\hline Laspeyresia pomonella & $\begin{array}{c}\text { Temperate Oceanic } \\
\text { Temperate Cold Continental } \\
\text { Temperate Cold Continental } \\
\text { Temperate Cold Continental } \\
\text { Temperate Cold Continental } \\
\text { Temperate Dry } \\
\text { Temperate Dry } \\
\text { Temperate Dry } \\
\text { Temperate Dry } \\
\end{array}$ & $\begin{array}{c}\text { Australia } \\
\text { NS Canada } \\
\text { Belgorod Russia } \\
\text { Poltava Ukraine } \\
\text { St. Petersburg Russia } \\
\text { Tadzikistan } \\
\text { Yessentuki Russia } \\
\text { Samarkand Uzbekistan } \\
\text { Karaganda Kazakstan } \\
\end{array}$ & $\begin{array}{l}-23.5 \\
-27.2 \\
-24.9 \\
-24.6 \\
-24.2 \\
-25.1 \\
-24.0 \\
-24.0 \\
-24.0 \\
\end{array}$ & $\begin{array}{l}\text { Shel'deshova, } 1967 \\
\text { MacPhee, } 1964 \\
\text { Shel'deshova, } 1967\end{array}$ \\
\hline Delia radicum & $\begin{array}{c}\text { Temperate Oceanic } \\
\text { Temperate Cold Continental }\end{array}$ & $\begin{array}{c}\text { BC Canada } \\
\text { UK } \\
\text { Estonia } \\
\text { St. Petersburg, Russia } \\
\text { QC Canada } \\
\text { MB Canada } \\
\end{array}$ & $\begin{array}{c}-24.8 \\
-24.0 \\
-25.2 \\
-24.8 \\
-24.1 \\
\text { ca. }-21.0\end{array}$ & $\begin{array}{l}\text { Turnock et al., } 1998 \\
\text { Turnock et al., } 1985 \\
\text { Merivee, } 1978 \\
\text { Košt'ál, } 1993 \\
\text { Turnock et al., } 1990\end{array}$ \\
\hline Lymantria dispar & $\begin{array}{l}\text { Temperate Warm Continental } \\
\text { Temperate Cold Continental }\end{array}$ & $\begin{array}{c}\text { CN USA } \\
\text { MS USA } \\
\text { QC Canada } \\
\end{array}$ & $\begin{array}{c}-30.2 \\
-27.7-0 \\
-30.2,30.5 \\
\end{array}$ & $\begin{array}{c}\text { Denlinger et al., } 1992 \\
\text { Sullivan \& Wallace, } 1972 \\
\text { Madrid \& Stewart, } 1981 \\
\end{array}$ \\
\hline Neodiprion sertifer & $\begin{array}{l}\text { Temperate Cold Continental } \\
\text { Temperate Cold Continental } \\
\text { Temperate Cold Continental } \\
\text { Temperate Cold Continental } \\
\text { Temperate Highlands } \\
\text { Temperate Highlands } \\
\text { Temperate Highlands } \\
\end{array}$ & $\begin{array}{l}\text { Estonia } \\
\text { Latvia } \\
\text { ON Canada } \\
\text { Japan } \\
\text { Austria } \\
\text { Germany } \\
\text { Switzerland } \\
\end{array}$ & $\begin{array}{c}-40.6 \\
-39.1,-34.5 \\
-32.1 \\
-30.8 \\
-32.0 \\
-31.3 \\
-31.1 \\
\end{array}$ & $\begin{array}{l}\text { Kopvillem \& Kuusik, 1971; } \\
\text { Merivee 1978; } \\
\text { Sullivan, 1965 }\end{array}$ \\
\hline $\begin{array}{l}\text { Exochomus } \\
\text { quadripustulatus }\end{array}$ & $\begin{array}{l}\text { Temperate Warm Continental } \\
\text { Temperate Cold Continental }\end{array}$ & $\begin{array}{l}\text { Czech Rep. } \\
\text { Russia }\end{array}$ & $\begin{array}{l}-24.0 \\
-13.5 \\
\end{array}$ & $\begin{array}{c}\text { Nedvěd, } 1993 \\
\text { Pantyukov, } 1971\end{array}$ \\
\hline $\begin{array}{l}\text { Craspedoleta } \\
\text { nebulosa }\end{array}$ & $\begin{array}{c}\text { Temperate Oceanic } \\
\text { Temperate Highlands } \\
\end{array}$ & $\begin{array}{c}\text { UK } \\
\text { Norway }\end{array}$ & $\begin{array}{l}-22.6 \\
-21.6 \\
\end{array}$ & Bird \& Hodkinson, 1999 \\
\hline $\begin{array}{l}\text { Pyrrhocoris } \\
\text { apterus }\end{array}$ & $\begin{array}{c}\text { Subtropical Dry Summer } \\
\text { Temperate Warm Continental }\end{array}$ & $\begin{array}{c}\text { Bulgaria } \\
\text { Czech Rep } \\
\end{array}$ & $\begin{array}{c}-9.5 \\
-16.8 \\
\end{array}$ & $\begin{array}{l}\text { Kalushkov \& Nedvěd, } 2000 \\
\text { Hodkova \& Hodek, } 1994\end{array}$ \\
\hline $\begin{array}{l}\text { Euproctis } \\
\text { chrysorrhea }\end{array}$ & $\begin{array}{c}\text { Temperate Cold Continental } \\
\text { Temperate Dry } \\
\end{array}$ & $\begin{array}{c}\text { Caucasus Russia } \\
\text { Tambov Russia }\end{array}$ & $\begin{array}{l}-21.8 \\
-21.2 \\
\end{array}$ & Pantyukov, 1964 \\
\hline Heliothis zea & $\begin{array}{c}\text { Subtropical Humid } \\
\text { Temperate Cold Continental }\end{array}$ & $\begin{array}{l}\text { AR USA } \\
\text { IL USA } \\
\end{array}$ & $\begin{array}{l}-22.2 \\
-22.3 \\
\end{array}$ & Roberts et al., 1972 \\
\hline Dalbulus maidis & $\begin{array}{c}\text { Subtropical Highlands } \\
\text { Temperate Cold Continental }\end{array}$ & $\begin{array}{l}\text { Mexico } \\
\text { OH USA }\end{array}$ & $\begin{array}{l}-21.1 \\
-22.3 \\
\end{array}$ & $\begin{array}{l}\text { Larsen et al., } 1993 \\
\text { Johnson \& Lee, } 1990\end{array}$ \\
\hline $\begin{array}{l}\text { Coleomegilla } \\
\text { maculata }\end{array}$ & Temperate Cold Continental & $\begin{array}{l}\text { MN USA } \\
\text { NY USA }\end{array}$ & $\begin{array}{l}-17.4 \\
-18.4 \\
\end{array}$ & Baust \& Morrissey, 1975 \\
\hline $\begin{array}{l}\text { Alsophila } \\
\text { pometaria }\end{array}$ & $\begin{array}{c}\text { Temperate Cold Continental } \\
\text { Temperate Dry }\end{array}$ & $\begin{array}{l}\text { NS Canada } \\
\text { AB Canada }\end{array}$ & $\begin{array}{l}-37.2 \\
-44.6 \\
\end{array}$ & $\begin{array}{l}\text { MacPhee, } 1964 \\
\text { Sømme, } 1964\end{array}$ \\
\hline $\begin{array}{l}\text { Scolytus } \\
\text { multistriatus }\end{array}$ & $\begin{array}{c}\text { Temperate Cold Continental } \\
\text { Boreal Continental }\end{array}$ & $\begin{array}{l}\text { USA } \\
\text { mid-Asia }\end{array}$ & $\begin{array}{l}-24.1 \\
-53.0 \\
\end{array}$ & $\begin{array}{c}\text { Truchan \& Butcher, } 1970 \\
\text { Lozina-Lozinskii, } 1974\end{array}$ \\
\hline $\begin{array}{l}\text { Neodiprion } \\
\text { p. banksianae }\end{array}$ & $\begin{array}{c}\text { Temperate Cold Continental } \\
\text { Boreal Continental }\end{array}$ & $\begin{array}{l}\text { ON Canada } \\
\text { ON Canada }\end{array}$ & $\begin{array}{l}-34.0 \\
-39.1 \\
\end{array}$ & Sullivan, 1965 \\
\hline
\end{tabular}


TABLE 3. Comparison of the SCP of species of freeze-tolerant insects with more than two records within or among different winter climates.

\begin{tabular}{|c|c|c|c|c|}
\hline Species & Climate & Location & $\mathrm{SCP}\left({ }^{\circ} \mathrm{C}\right)$ & Reference \\
\hline Phyllodecta laticollis & Temperate Highlands & Norway & $\begin{array}{l}-7.0 \\
-5.0\end{array}$ & $\begin{array}{l}\text { Van der Laak, } 1982 \\
\text { Zachariassen, } 1980\end{array}$ \\
\hline Melasoma collaris & Temperate Highlands & Norway & $\begin{array}{l}-5.0 \\
-7.3\end{array}$ & $\begin{array}{c}\text { Zachariassen, } 1980 \\
\text { Gehrken \& Southon, } 1997\end{array}$ \\
\hline Pytho depressus & Temperate Highlands & Norway & $-7.0,-5.0$ & Zachariassen 1977, 1980 \\
\hline Pterostichus brevicornis & Boreal Continental & AK USA & $-10.0,-11.0$ & Miller, 1969, 1982 \\
\hline Belgica antarctica & Polar Continental & $\begin{array}{l}\text { Galindez I. } \\
\text { Palmer Sta }\end{array}$ & $\begin{array}{l}-6.2 \\
-5.7\end{array}$ & $\begin{array}{c}\text { Block, } 1982 \\
\text { Baust \& Edwards, } 1979\end{array}$ \\
\hline Ostrinia nubilalis & $\begin{array}{l}\text { Temperate Warm Continental } \\
\text { Temperate Cold Continental }\end{array}$ & $\begin{array}{l}\text { Yugoslavia } \\
\text { St. Petersburg } \\
\text { Russia } \\
\text { MN USA } \\
\text { WI USA }\end{array}$ & $\begin{array}{l}-22.5 \\
-25.0 \\
-22.0 \\
-18.6\end{array}$ & $\begin{array}{c}\text { Grubor-Lajsic et al., } 1991 \\
\text { Lozina-Lozinskii, } 1974 \\
\text { Barnes \& Hodson, } 1956 \\
\text { Hanec \& Beck, } 1960\end{array}$ \\
\hline Pytho planus (americanus) & $\begin{array}{l}\text { Temperate Highlands } \\
\text { Polar Continental }\end{array}$ & $\begin{array}{l}\text { BC Canada } \\
\text { NWT Canada }\end{array}$ & $\begin{array}{l}-6.6 \\
-6.0\end{array}$ & $\begin{array}{c}\text { Ring, } 1982 \\
\text { Ring \& Tesar, } 1980\end{array}$ \\
\hline Pytho planus (deplanatus) & Temperate Highlands & BC Canada & -54 & Ring, 1982 \\
\hline Eurosta solidaginis & $\begin{array}{l}\text { Subtropical Dry } \\
\text { Temperate Dry } \\
\text { Temp. Cold Cont. }\end{array}$ & $\begin{array}{c}\text { TX, USA } \\
\text { AB Canada } \\
\text { ON Canada } \\
\text { MN USA } \\
\text { NY USA } \\
\end{array}$ & $\begin{array}{c}-18.2,-10.0 \\
-10.1,-9.6 \\
-10.5 \\
-10.2 \\
-13.7 \\
\end{array}$ & $\begin{array}{c}\text { Baust et al., } 1979 \\
\text { Sømme, 1964, } 1978 \\
\text { Rickards et al., } 1987 \\
\text { Baust \& Lee, } 1981 \\
\text { Baust et al., } 1979\end{array}$ \\
\hline Eurytoma gigantea & $\begin{array}{l}\text { Subtropical Dry } \\
\text { Temp. Cold Cont. } \\
\text { Temperate Dry }\end{array}$ & $\begin{array}{c}\text { TX USA } \\
\text { NY USA } \\
\text { AB Canada } \\
\end{array}$ & $\begin{array}{l}-27.0 \\
-23.0 \\
-49.0\end{array}$ & $\begin{array}{l}\text { Baust et al., } 1979 \\
\text { Sømme, } 1964\end{array}$ \\
\hline Eurytoma obtusiventris & $\begin{array}{l}\text { Subtropical Dry } \\
\text { Temp. Cold Cont. }\end{array}$ & $\begin{array}{l}\text { TX, USA } \\
\text { NY, USA }\end{array}$ & $\begin{array}{l}-29.0 \\
-29.0\end{array}$ & Baust et al., 1979 \\
\hline Mordellistena unicolor & $\begin{array}{l}\text { Subtropical Dry } \\
\text { Temp. Cold Cont. }\end{array}$ & $\begin{array}{l}\text { TX, USA } \\
\text { NY, USA }\end{array}$ & $\begin{array}{l}-26.0 \\
-26.0\end{array}$ & $\begin{array}{c}\text { Duman \& Montgomery, } 1991 \\
\text { Baust et al., } 1979\end{array}$ \\
\hline Phosphuga atrata & $\begin{array}{l}\text { Temperate Highlands } \\
\text { Temp. Cold Cont. } \\
\text { Temp. Cold Cont. }\end{array}$ & $\begin{array}{l}\text { Norway } \\
\text { Japan } \\
\text { Estonia }\end{array}$ & $\begin{array}{l}-5.5 \\
-8.3 \\
-5.7\end{array}$ & $\begin{array}{c}\text { Zachariassen, } 1980 \\
\text { Ohyama \& Asahina, } 1972 \\
\text { Merivee, } 1978\end{array}$ \\
\hline
\end{tabular}

\section{PROPORTIONS OF SPECIES ADOPTING FREEZE-TOLERANCE VS -SUSCEPTIBILITY}

The incidence of freeze-tolerance among species overwintering in exposed habitats tended to be lower than among those in partially-protected or protected habitats (Table 4). However, the differences were statistically significant only among species in Temperate Zone Cold Continental and Dry climates. With the data pooled for all habitats within climatic zones, the incidence of freezetolerance was significantly higher in the Boreal and Polar zones than in the Tropical and Temperate zones.

Differences between the incidence of freeze-tolerance among insects in the southern and northern hemispheres led Sinclair et al. (2003) to conclude that this strategy would be selected for under conditions with "the certainty of severe, sub-zero cold" and "the unpredictability of non-frigid freeze-thaw events". The high incidence of freeze-tolerance in Polar and Boreal climates supports the first case, but the incidence is generally low among overwintering insects in exposed habitats in the Temperate zone (Table 4). Within the Temperate zone, partlyexposed and exposed overwintering habitats in the Oceanic and Warm Continental have unpredictably variable winters in which "non-frigid, freeze-thaw events" are likely, and would be expected to favour the freezetolerant strategy. Although the incidence of freezetolerance is highest in the exposed habitats of Warm Continental climates, it is also high in protected habitats in these climates (Table 4). The overwintering microhabitat may also play a role. For example, among beetle species inhabiting rotten stumps in the Temperate Oceanic zone of France (Vernon et al., 1996), the incidence of freeze-tolerance is high although they are protected from rapid temperature changes. Contact with water may prevent supercooling and necessitate the ability to tolerate freezing (Fields \& McNeil, 1986).

Freeze-tolerance has not been recorded among the eggs of overwintering terrestrial Hemimetabola or Holometabola (Table 5). In the other developmental stages, the incidence of freeze-tolerance was significantly $(P<0.02)$ higher among the Holometabola $(27 \%)$ than among the Hemimetabola (12\%). Among Holometabola the incidence of freeze-tolerance was significantly lower for pupae than for larvae or adults, but there were no consistent differences in the incidence among species overwintering in different habitats. In the Hemimetabola, there were no significant differences in the incidence of freeze- 
TABLE 4. The percentage of freeze-tolerant species among overwintering terrestrial insects by overwintering site and climatic zone. (Number of records in parentheses) ${ }^{1}$.

\begin{tabular}{lcccc}
\hline \multirow{2}{*}{ Climatic zone } & \multicolumn{3}{c}{ Freeze tolerance (\%) } \\
\cline { 2 - 4 } & Protected habitat & Partially-protected habitat & Exposed habitat & All habitats \\
\hline Tropical & $100(3)$ & $0(29)$ & $100(1)$ & $9(33) \mathrm{z}$ \\
Subtropical & $50(4)$ & $25(8)$ & $31(13)$ & $32(25) \mathrm{zyx}$ \\
Temperate (all) & $30(92) \mathrm{a}$ & $27(121) \mathrm{a}$ & $18(79) \mathrm{a}$ & $26(292) \mathrm{x}$ \\
Oceanic & $47(19)$ & $15(20)$ & $0(10)$ & $24(49)$ \\
Warm Continental & $33(6)$ & $7(13)$ & $50(10)$ & $28(29)$ \\
Cold Continental & $21(44) \mathrm{b}$ & $36(66) \mathrm{b}$ & $13(38) \mathrm{a}$ & $26(148)$ \\
Dry & $35(23) \mathrm{b}$ & $23(22) \mathrm{a}$ & $19(21) \mathrm{a}$ & $26(66)$ \\
Boreal & $50(4)$ & $20(5)$ & $59(17)$ & $50(26) \mathrm{y}$ \\
Polar & - & $71(17)$ & - & $71(17) \mathrm{y}$ \\
All zones & $34(103) \mathrm{a}$ & $27(180) \mathrm{a}$ & $25(110) \mathrm{a}$ & \\
\hline
\end{tabular}

${ }^{1}$ Subdivided contingency tables were used to test if habitats (rows) or if climate zones (columns) affect the proportion that was freeze-tolerant. Fisher exact test and Bonferroni inequality were used to adjust tests and $P$ values when required, $P<0.05$, no test if there were insufficient numbers.

tolerance among the developmental stages or among habitats (Table 5).

\section{WINTER CLIMATES AND INSECT COLD INJURY}

The ability to survive non-freezing cold injury has long been recognized a factor in insect coldhardiness (see reviews by Danks, 1978; Bale, 1987; Lee, 1989; Fields, 1992; Sømme, 1999). Despite this, information on the manner in which insects have adapted to the challenges of extended exposures to low temperatures above the SCP is limited. Recent reviews persist in maintaining that the two main strategies for insect survival in cold are freezetolerance and freeze-susceptibility (Sinclair, 1999; Sømme, 1999; Renault et al., 2002; Sinclair et al., 2003).

TABLE 5. The percentage of freeze-tolerant species among terrestrial insects by overwintering site among the developmental stages of Holometabola and Hemimetabola ${ }^{1}$.

\begin{tabular}{lcccc}
\hline \multirow{2}{*}{ Stage } & \multicolumn{4}{c}{ Freeze tolerance (\%) } \\
\cline { 2 - 5 } & $\begin{array}{c}\text { Protected } \\
\text { habitat }\end{array}$ & $\begin{array}{c}\text { Pally protected } \\
\text { habitat }\end{array}$ & $\begin{array}{c}\text { Exposed } \\
\text { habitat }\end{array}$ & $\begin{array}{c}\text { All } \\
\text { habitats }\end{array}$ \\
\hline Holometabola & & & & \\
Eggs & $0(1)$ & $0(11)$ & $0(14)$ & $0(26) \mathrm{z}$ \\
Larvae & $20(30) \mathrm{a}$ & $53(64) \mathrm{b}$ & $26(29) \mathrm{a}$ & $37(123) \mathrm{y}$ \\
Pupae & $0(18) \mathrm{a}$ & $8(26) \mathrm{b}$ & $50(4) \mathrm{b}$ & $8(48) \mathrm{z}$ \\
Adults & $52(46) \mathrm{b}$ & $21(73) \mathrm{a}$ & $45(22) \mathrm{b}$ & $30(141) \mathrm{y}$ \\
All Stages & $24(95) \mathrm{a}$ & $29(174) \mathrm{a}$ & $25(69) \mathrm{a}$ & \\
Hemimetabola & & & & \\
Eggs & $0(1)$ & $0(1)$ & $0(8)$ & $0(10) \mathrm{z}$ \\
Nymphs & $0(3)$ & $100(1)$ & $0(10)$ & $7(14) \mathrm{z}$ \\
Adults & $100(1)$ & $13(15)$ & $17(12)$ & $18(28) \mathrm{z}$ \\
All Stages & $20(5) \mathrm{a}$ & $18(17) \mathrm{a}$ & $7(30) \mathrm{a}$ & \\
\hline
\end{tabular}

${ }^{1}$ Subdivided contingency tables were used to test if habitats (rows) or if stage (columns) affect the proportion that was freeze-tolerant. Holometabola and Hemimetabola tested separately. Fisher exact test and Bonferroni inequality were used to adjust tests and $P$ values when required, $P<0.02$, no test if there were insufficient numbers.
It would be more profitable for research to consider that the two principal physiological adaptations to cold are the avoidance of freezing injury and the avoidance of nonfreezing cold injury. Our knowledge of the effects of low temperatures on the physiological processes that are involved in cold injury and the adaptations that have been used to avoid this injury is rudimentary. Potential causes of death at low, non-freezing temperatures are reviewed by Ramløv (2000) and Renault et al. (2002).

Consensus on the parameters that need to be measured to characterize the level of cold injury resistance in insects will not be reached until much more data has been accumulated, but we believe that the following concepts are worth pursuing.

\section{Upper Limit of the Cold Injury Zone (ULCIZ)}

The ULCIZ, the lowest temperature at which no significant mortality occurred during an ecologically relevant duration of exposure, is an important characteristic. This concept was developed in studies of freeze-susceptible insects overwintering in the soil of Temperate Oceanic and Temperate Cold Continental climates (Turnock et al., 1983, 1985, 1998; Turnock \& Bilodeau, 1992; Turnock, 1993; Turnock \& Carl, 1995). Nedvěd (1998) presented calculations of the ULCIZ for seven species, showing that the value was below $10^{\circ} \mathrm{C}$ for a tropical species, Nauphoeta cinerea Olivier, $1.3^{\circ} \mathrm{C}$ for a Collembolan overwintering in the surface litter in a Temperate Oceanic climate, and -6.6 to $-15.6^{\circ} \mathrm{C}$ among three species overwintering in the soil in a Temperate Cold Continental climate. Among these three species, the ULCIZ $\left(-5^{\circ} \mathrm{C}\right.$ to $\left.-15^{\circ} \mathrm{C}\right)$ varied parallel to the SCP $\left(-20.3\right.$ to $\left.-26.4^{\circ} \mathrm{C}\right)$ (Turnock, 1993; Nedvěd, 1998). These species may differ in the soil depth at which they overwinter and therefore are exposed to different winter temperatures. The change in the ULCIZ of Eurithia consobrina (Meigen) from $-7.5^{\circ} \mathrm{C}$ among overwintering puparia that were the progeny of adults from Germany (Temperate Oceanic climate) to $-17.5^{\circ} \mathrm{C}$ for their progeny reared for 5-10 generations with diapause-inducing larval rearing 
temperatures and cold exposures of 140 days, shows that this parameter can be altered by selection (Turnock \& Carl, 1995).

\section{Predicting Survival}

The rate at which survival decreases with increased stress from lower temperatures and longer exposures, involves the interaction of two variables, and is more difficult to characterize. This relationship has been described by regression analysis of duration of exposure for several temperatures (e.g. Merivee, 1978), and a regression equation that combined temperatures and exposures within the cold injury zone was developed to predict non-freezing survival (Turnock et al., 1983; Lamb et al., 1985; Turnock et al., 1990; Turnock \& Bilodeau, 1992; Turnock, 1993; Turnock \& Carl, 1995; Turnock et al., 1998). The calculation of negative degree-days (DD) below $0^{\circ} \mathrm{C}$ assumes that a particular DD accumulation has the same impact on survival, regardless of the combination of temperature and time that is used (Bale, 1996). The inclusion of temperatures above the ULCIZ, where no cold injury occurs, is an obvious flaw in this approach. Nedvěd (1998) reviewed methods of describing this relationship and proposed the use of the product of time and temperature exposure within the cold injury zone, the sum of injurious temperatures (SIT), in day-degrees (DD), or Kelvin-days (KD) (Nedvěd, 1998). This approach avoids the problem noted by Bale (1996), and has merit as a single parameter to characterize the response of a species to non-freezing stress (temperature and duration of exposure) within the cold injury zone. Nedvěd (2000b) calculated the time needed to cause $50 \%$ mortality $\left(\mathrm{LT}_{50}\right)$ to illustrate the response to cold injury of Stenotarsus rotundus Arrow. However, information on the ULCIZ and SIT is only available for very few species. Much more data are needed to test the usefulness of these parameters in helping us to understand the adaptations of species to avoid cold injury and their relationship to adaptations to avoid freezing injury.

The concept of ULCIZ and SIT may apply to freezetolerant species. Some species do not survive exposure to temperatures several degrees below their SCP (Fields \& McNeil, 1986, 1988; Vernon et al., 1996; Sømme, 1999). It seems likely that this mortality is caused by nonfreezing cold injury, but definitive experiments on time/temperature relationships and the mechanism causing injury have not been reported.

The concept of ULCIZ and SIT would be of little value for insects which die only if frozen, i.e no mortality occurs regardless of the temperature or duration of exposure at temperatures above the SCP (Bale, 1993; Nedvěd, 2000a). However, the research on which this class is based (e.g. Rickards et al., 1987; Tenow \& Nilssen, 1990) does not include a range of time/temperature experiments, and therefore does not eliminate the possibility that death from cold injury occurs at temperatures above the SCP. Such species could provide evidence about changes in the ULCIZ and SIT that have occurred in insects adapted to extreme temperatures, if experiments were conducted with a range of ecologically-relevant temperatures and exposures.

\section{Other Parameters}

Estimates of the Lethal Time to $50 \%$ mortality (Ltime 50) and of the Lethal Temperature for 50\% mortality (Ltemp 50) have been used to describe the level of coldhardiness to non-freezing cold injury. The common design in such studies has been to determine the decrease in survival among subsamples placed at a constant temperature for different exposure periods (Pullin et al., 1991) or among subsamples placed at a fixed period of time at a series of temperatures (van der Woude \& Verhoef, 1986). These parameters are not based on a range of both temperatures and durations of exposure, so they are not adequate to describe mortality caused by non-freezing cold injury. However, they may be useful for specific comparisons.

\section{Repair of Cold Injury}

Cold injury may be repaired if suitable temperatures occur and this adaptation feature appears to be particularly important in species that overwinter in habitats with variable winter temperatures, e.g. ground-surface litter in Temperate Warm Continental, Oceanic, and Highland climates (Casagrande \& Haynes, 1976; Nedvěd et al., 1998; Sinclair, 2001). This characteristic was also identified in a species overwintering in the soil, where no such temperature reversals occur (Turnock \& Bodnaryk, 1991), but there is no information on how widely it occurs in other species. The common experimental design for investigating acclimation ignores the possibility of repairing cold injury. Experiments where insects exposed to a low temperature followed by a cool temperature are compared to those exposed to cool followed by cold temperatures with survival checked at a warm temperature (e.g. $-20^{\circ} / 5^{\circ} / 25^{\circ} \mathrm{C}$, compared to $5^{\circ} /-20^{\circ} / 25^{\circ} \mathrm{C}$; Denlinger et al., 1992) are not adequate to determine if acclimation does occur, because increased coldhardiness in the second group could be the result of repair of cold injury at the warm temperature. Samples exposed to a low temperature should be kept for the duration of a normal winter at a temperature above the ULCIZ, but below the temperature at which cold injury can be repaired. For Mamestra configurata (Walker) this zone lies between $-5^{\circ} \mathrm{C}$ (ULCIZ) and ca. $10^{\circ} \mathrm{C}$ (Turnock \& Bodnaryk, 1991, 1993). Temperatures within this zone neither cause cold injury nor allow the repair of the injury occurring at lower temperatures.

The zone between the minimum temperature at which normal activities and development occur and the ULCIZ needs more attention in coldhardiness research. In seasonal climates, most insect species are in diapause or quiescence to minimize the physiological stresses and to allow the completion of diapause development (Tauber et al., 1986). Within this zone, temperature does not affect survival, provided the duration of exposure does not exceed the normal winter period. The development of rearing techniques for species living in seasonally cold climates usually identifies optimum overwintering tem- 
peratures, those at which diapause is broken and mortality is minimal. Such temperatures, maintained for a period approximating natural winter length, can be used as the holding temperature in experiments to determine survival in cold injury studies, as well as giving a basis for experiments to determine the limits of this zone. We propose that it be named the "maintenance zone".

\section{DISCUSSION}

The results of coldhardiness research should describe the mechanisms that insects have developed to protect themselves from low temperature, allow the prediction of overwintering survival in a particular habitat, and estimate the probability of a species surviving in locations outside its range. The question as to how well insects are adapted to their overwintering niches can be only partially answered from the available data. The system of classification of winter climates and habitats can provide a useful framework in examining the relationship between the conditions in the overwintering habitats and the level of coldhardiness.

The SCP is the best documented parameter for describing levels of coldhardiness. Among freezesusceptible species in partially-protected and exposed habitats the SCP decreased significantly with increased severity of the overwintering habitat. In addition, the highest SCP decreased with increasing severity of the overwintering habitat, indicating that a minimum level of protection against freezing was needed to survive in each habitat. No such trend occurred among species in protected habitats, suggesting that freezing is not the major threat to their overwintering survival. The range of values was high, at least $20^{\circ} \mathrm{C}$, regardless of the climatic zone or habitat. Some of the variability is undoubtably due to the division of overwintering habitats into only three broad categories. In other cases, mobile species inhabiting more than one climatic zone may retain the SCP necessary to survive in the coldest part of their range. The SCP may also reflect an adaptation to stresses other than low temperature (metabolic stability during periods of diapause or quiescence, protection against desiccation) that lower the SCP. The compounds giving such protection may also be cryoprotectants, giving a SCP below that needed to avoid freezing. This basic SCP, when lower than minimum temperatures in an overwintering habitat, precludes the need for further adaptation in the SCP, and can be considered as a pre-adaptation for surviving low temperatures. The mean SCP is a useful parameter for describing the ability of a species to survive freezing, but its value as a predictor of overwintering survival, or in estimating the probability of a species surviving under new conditions in their overwintering habitat is limited. Changes in the probability of freezing could occur either through an extension in the geographical range or because of climatic changes. Useful predictions might be made for species overwintering in exposed and some partially-protected habitats, but not for those in protected habitats.

There is less data for freeze-tolerant species, and the SCP was not significantly related to the severity of the climatic zone and habitat. The range of SCP values increased with severity and from protected to exposed habitats. Unlike freeze-susceptible species, some species found in very cold overwintering habitats have a SCP about the same as for species found in the warmest climates and habitats. A few species have very low SCPs, seeming to combine the advantages of cryoprotectants to avoid freezing with the use of nucleators to avoid the consequences of freezing. Freeze-tolerance, as a method of avoiding freezing injury, may occur more frequently in climatic zones and habitats with fluctuating winter temperatures and in those with very low temperatures.

Non-freezing cold injury has been rather poorly studied. The mechanisms for protecting insects from nonfreezing injury are different from those protecting from freezing, i.e., some species adequately protected from freezing in their overwintering habitat are susceptible to non-freezing injury and death. The converse may also occur, insects that appear not to be affected by nonfreezing injury die only when temperatures in their overwintering habitat are below the SCP. Non-freezing injury has been clearly demonstrated in freeze-susceptible species, and probably occurs in freeze-tolerant species. In the latter, non-freezing injury could occur either above or below the SCP, but neither has been carefully studied. The duration of exposure is an important element in nonfreezing injury and death, as the trauma accumulates with increasing time and decreasing temperature. If an insect is warmed to a temperature at which normal metabolic activity occurs before the trauma is too severe, the injury may be repaired.

Insects overwintering in habitats with variable, unpredictable temperatures need special adaptations to avoid both freezing and non-freezing mortality. In these habitats, freeze-tolerance may be a preferred method of avoiding freezing injury, and a mechanism to repair nonfreezing injury may be necessary.

There is not yet consensus about the parameters that should be used to describe the level of resistance to nonfreezing injury or to predict overwintering survival and the probability of surviving in a new environment. Parameters that could be useful include:

(1) The lower thermal limit for normal metabolic activity. This may also be the lowest temperature at which non-freezing cold injury can be repaired.

(2) The neutral or maintenance zone lies between the lower thermal limit for active metabolism and the highest temperature at which cold injury occurs (ULCIZ). Within this zone, neither cold injury nor the repair of previous cold injury can occur. For insects in habitats with seasonal cold stresses, it includes the optimum temperature for survival of overwintering insects.

(3) Parameters describing the cold injury zone. The ULCIZ defines the highest temperature at which cold injury occurs within a time period reasonable for the duration of low temperatures in the overwintering habitat. Defining the lower limit of the cold injury zone is more complex. Simply, it is the temperature at which cold injury causes death in a very short time, perhaps 1 day, 
but freeze-susceptible insects may die from freezing before this lower limit is reached. In such cases, the SCP defines the lower limit of the cold injury zone. Mortality due to cold injury may occur among freeze-tolerant species both above and below their SCP. Mortality occurs at temperatures slightly below the SCP, but no data is available as to the cause of this mortality, or the role of duration of exposure in causing it.

(4) The effect of time and temperature within the cold injury zone can be described by a form of the negative degree-days, such as SIT. Such an equation would also provide a mechanism for estimating survival under combinations of time/temperatures within the range of conditions within the habitat, and a prediction of the probable survival of a species in a new climatic zone. These data would be useful for all species, regardless of how they avoid freezing injury.

(5) The mean SCP is useful for some descriptive purposes, but the frequency distribution of the SCPs will be necessary to predict overwintering survival for some freeze-susceptible species in habitats in which freezing intervenes before death from non-freezing injury.

With such data and a knowledge of the temperatures of exposure, models to predict survival could be prepared. Different types of winter stresses would require different approaches to predictive models.

The simplest model would be for species in which freezing is the main cause of overwintering mortality. The only parameters in a predictive model of overwintering survival would be the minimum temperature and the frequency distribution of the SCP. The complete absence of non-freezing mortality is probably rare, but in some species the proportion dying of such injury under usual exposures might be low enough to ignore in predicting survival. This model would be most likely to apply to freeze-susceptible species in exposed habitats in climatic zones with low temperatures.

In species where non-freezing cold injury is the main cause of overwintering mortality, the predictive equation for survival would include both time and temperature. Various mathematical approaches for predicting survival such as SIT (negative degree-days), regression analysis, and other mathematical approaches have been suggested, but not widely tested (Nedvěd, 1998). This approach is most likely to apply to freeze-susceptible insects overwintering in protected habitats.

Freeze-tolerance has the same effect as lowering the $\mathrm{SCP}$, it removes freezing injury as a threat to survival. Predicting survival in habitats in which temperatures remain below the lower thermal limit would be based only upon susceptibility to cold injury. Habitats in which temperatures fluctuate between the cold-injury zone and above the lower thermal limit for metabolic activity allow the possibility of repair/reversal of cold injury. Prediction of survival in such habitats would include information on the parameters of the repair process.

ACKNOWLEDGEMENTS. The help given by R.A. Raditz and D. Phillips, Meteorological Service, Environment Canada; W. Block, British Antarctic Survey; T. Papakyriakou and A. Lan- glois, Department of Geography, University of Manitoba; D. Blair, University of Winnipeg; and L. Fishback, Churchill Northern Studies Centre, Churchill, Manitoba, with the literature on weather, climate, and descriptions of climatic conditions is gratefully acknowledged. Many friends and colleagues in the coldhardiness research community, particularly L. Sømme, H. Ramløv, O. Nedvěd and W. Block, have been encouraging and helpful. Over the years, W.O. Pruitt Jr., Department of Zoology, University of Manitoba, has shared his knowledge and appreciation of snow, which contributed to the development of this analysis. N. White and C. Demianyk reviewed the manuscript before submission.

\section{REFERENCES}

Bailey W.G., Oke T.R. \& Rouse W.R. 1997: The Surface Climates of Canada. McGill-Queens Univ. Press, Montreal \& Kingston, $484 \mathrm{pp}$.

BALE J.S. 1987: Insect cold hardiness: freezing and supercooling - an ecophysiological perspective. J. Insect Physiol. 33: 899-908.

BALE J.S. 1991: Insects at low temperature: a predictable relationship? Func. Ecol. 5: 291-298.

Bale J.S. 1993: Classes of insect coldhardiness. Func. Ecol. 7: 751-753.

BALE J.S. 1996: Insect cold hardiness: a matter of life and death. Eur. J. Entomol. 93: 369-382.

Bale J.S., Harrington R. \& Clough M.S. 1988: Low temperature mortality of the peach-potato aphid Myzus persicae. Ecol. Entomol. 13: 121-129.

Barnes B. \& Hodson A.C. 1956: Low temperature tolerance of the European corn borer in relation to winter survival in Minnesota. J. Econ. Entomol. 49: 19-24.

Baust J.G. \& Edwards J.S. 1979: Mechanisms of freezing tolerance in an Antarctic midge, Belgica antarctica. Physiol. Entomol. 4: $1-5$.

Baust J.G. \& LeE R.E. JR. 1981: Divergent mechanisms of frost-hardiness in two populations of the gall fly, Eurosta solidaginis. J. Insect Physiol. 27: 485-490.

BAUST J.G. \& MoRRISSEY R.E. 1975: Supercooling phenomenon and water content independence in the overwintering beetle, Coleomegilla maculata. J. Insect Physiol. 21: 1751-1754.

Baust J.G., Grandee R., Condon G. \& Morrissey R.C. 1979: The diversity of strategies utilized by separate populations of gall insects. Physiol. Zool. 52: 572-580.

BennetT L.E. \& Lee R.E. JR. 1989: Simulated winter to summer transition in diapausing adults of the lady beetle (Hippodamia convergens): supercooling point is not indicative of coldhardiness. Physiol. Entomol. 14: 361-367.

Bird J.M. \& HodKInSON I.D. 1999: Species at the edge of their range: The significance of the thermal environment for the distribution of congeneric Craspedolepta species (Sternorrhyncha: Psylloidea) living on Chamerion angustifolium (Onagraceae). Eur. J. Entomol. 96: 103-109.

BLOCK W. 1982: Supercooling points of insects and mites on the Antarctic Peninsula. Ecol. Entomol. 7: 1-8.

BROwn R.D. 2000: Northern hemisphere snowcover variability and change, 1915-1997. J. Climate 13: 2339-2355.

Casagrande R.A. \& Haynes D.L. 1976: A predictive model for cereal leaf beetle mortality from sub-freezing temperatures. Envir. Entomol. 5: 761-769.

Cloudsley-Thompson J.L. 1962: Microclimates and the distribution of terrestrial arthropods. Annu. Rev. Entomol. 7: 199-222.

Cloudsley-Thompson J.L. 1970: Terrestrial Invertebrates. In Whittow G.C. (ed.): Comparative Physiology of Thermoregu- 
lation. Vol. I. Academic Press, New York \& London, pp. 15-77.

DANKS H.V. 1978: Modes of seasonal adaptation in the insects. I. Winter survival. Can. Entomol. 110: 1167-1205.

DANKS H.V. 1996: The wider integration of studies of insect coldhardiness. Eur. J. Entomol. 93: 383-403.

DANKS H.V., KUKAL O. \& Ring R.A. 1994: Insect cold-hardiness: insights from the Arctic. Arctic 47: 391-404.

Denlinger D.L., Lee R.E. JR., Yocum G.D. \& KuKal O. 1992: Role of chilling in the acquisition of cold tolerance and the capacitation to express stress proteins in diapausing pharate larvae of the Gypsy Moth, Lymantria dispar. Arch. Insect Biochem. Physiol. 21: 271-280.

Duman J.G. 1980: Factors involved in overwintering survival of the freeze tolerant beetle, Dendroides canadensis. J. Comp. Physiol. (B) 136: 53-59.

Duman J.G. \& Montgomery S.L. 1991: Subzero temperature adaptions in arthropods from the summit of Mauna Kea, Hawaii. J. Exp. Zool. 259: 409-412.

DyE D.G. 2002: Variability and trends in the annual snow-cover cycle in Northern Hemisphere land areas, 1972-2000. Hydrol. Processes 16: 3065-3077.

FIELDS P.G. 1992: The control of stored-product insects and mites with extreme temperatures. J. Stored Prod. Res. 28: 89-118.

Fields P.G. \& McNeIl J.N. 1986: Possible dual cold-hardiness strategies in Cisseps fulvicollis (Lepidoptera: Arctiidae). Can. Entomol. 118: 1309-1311.

Fields P.G. \& McNeIL J.N. 1988: The cold-hardiness of Ctenucha virginica (Lepidoptera: Arctiidae) larvae, a freezingtolerant species. J. Insect Physiol. 34: 269-277.

French H.M. \& Slaymaker O. 1993: Canada's Cold Environments. McGill-Queens Univ. Press, Montreal \& Kingston, $340 \mathrm{pp}$.

GeHRKen U. 1984: Winter survival of an adult bark beetle Ips acuminatus. J. Insect Physiol. 30: 421-429.

GeHRKEN U. 1992: Inoculative freezing and thermal hysteresis in the adult beetles Ips acuminatus and Rhagium inquisitor. $J$. Insect Physiol. 38: 519-524.

GeHRKEN U. \& Southon T.E. 1997: Effect of temperature on coldhardiness and tissue ice formation in the adult Chrysomelid beetle Melasoma collaris L. J. Insect Physiol. 43: 587-593.

Geiger R. 1950: The Climate near the Ground. Harvard University Press, Cambridge, USA, 482 pp.

GREEN G.W. 1962: Low winter temperatures and the European pine shoot moth, Rhyacionia buoliana (Schiff.) in Ontario. Can. Entomol. 94: 314-336.

Grody N.C. \& Basist A.N. 1996: Global identification of snowcover using SSM/I measurements. Trans. Geosci. Remote Sensing 34(1): 237-249.

Grubor-Lajsic G., Block W., Palanacki V. \& Glumac S. 1991: Cold hardiness parameters of overwintering diapause larvae of Ostrinia nubilalis in Vojvodina, Yugoslavia. Cryo-Letters 12: $177-182$.

Hanec W. \& Beck S.D. 1960: Cold hardiness in the European corn borer, Pyrausta nubilalis (Hübn.). J. Insect Physiol. 5: $169-180$.

Hansen T. \& Merivee E. 1971: Cold hardiness of the cabbage butterflies Pieris brassicae L. and Pieris rapae L. Eesti NSV Tead. Akad. Toim. Biol. 20: 298-303.

Hodková M. \& Hodek I. 1994: Control of diapause and supercooling by the retrocerebral complex in Pyrrhocoris apterus. Entomol. Exp. Appl. 70: 237-245.
JING X.H. \& KANG L. 2003. Geographical variation in egg coldhardiness: a study on the adaptation strategies of the migratory locust, Locusta migratoria L. Ecol. Entomol. 28: 151-158.

JoHNSON S.L. \& LEE R.E. JR. 1990: Regulation of supercooling and nucleation in a freeze intolerant beetle (Tenebrio molitor). Cryobiology 27: 562-568.

KalushKov P. \& NedvĚd O. 2000: Coldhardiness of Pyrrhocoris apterus (Heteroptera: Pyrrhocoridae) from central and southern Europe. Eur. J. Entomol. 97: 149-153.

King J.C. \& TuRner J. 1997: Antarctic Meteorology and Climatology. Cambridge University Press, 425 pp.

KLoK C.J. \& Chown S.L. 1997: Critical thermal limits, temperature tolerance and water balance of a sub-antarctic caterpillar, Pringleophaga marioni (Lepidoptera: Tineidae). J. Insect Physiol 43: 685-694.

KöPpen W. 1931: Grundriss der Klimakunde. De Gruyter, Berlin, 380 pp.

KopvilLem H. \& KuUsiK A. 1971: On the cold-hardiness of overwintering eggs of the European pine sawfly, Neodiprion sertifer (Geoffr.) and its parasite Achrysocharella ruforum (Krausse). Eesti NSV Tead. Akad. Toim. Biol. 20: 291-297.

KošŤÁL V. 1993: Cold-hardiness and supercooling capacity in diapausing and nondiapausing stages of the cabbage root fly Delia radicum. Cryobiology 30: 524-531.

Lamb R.J., Turnock W.J. \& Hayhoe H.N. 1985: Winter survival and outbreaks of Bertha armyworm, Mamestra configurata (Lepidoptera: Noctuidae), on canola. Can. Entomol. 117: 727-736.

LARSEN K.H., LEe R.E. JR. \& NaUlt L.R. 1993: Influence of developmental conditions on coldhardiness of adult Dalbulus leafhoppers: implications for overwintering. Entomol. Exp. Appl. 67: 99-108.

LeE R.E. JR. 1980: Physiological adaptations of Coccinellidae to supranivean and subnivean hibernacula. J. Insect Physiol. 26: $138-138$.

LEE R.E. JR. 1989: Insect cold-hardiness: to freeze or not to freeze. Bioscience 39: 308-313.

LozINA-LozInSKII L.K. 1974: Studies in Cryo-Biology. John Wiley, New York, 259 pp.

MACPheE A.W. 1964: Cold-hardiness, habitat, and winter survival of some orchard arthropods in Nova Scotia. Can. Entomol. 96: 617-625.

MADRID F.J. \& STEWART R.K. 1981: Ecological significance of coldhardiness and winter mortality of eggs of the Gypsy Moth Lymantria dispar L., in Quebec. Envir. Entomol. 10: 586-589.

Merivee E. 1978: Cold-Hardiness in Insects. Acad. Sci. Estonian SSR, Tallin, 188 pp. (in Estonian, English abstr.).

MiLLER L.K. 1969: Freezing tolerance in an adult insect. Science 166: 105-106.

MiLLER L.K. 1982: Coldhardiness strategies of some adult and immature insects overwintering in Interior Alaska. Comp. Biochem. Physiol. (A) 73: 595-604.

NEDVĚD O. 1993: Comparison of coldhardiness in two ladybird beetles (Coleoptera: Coccinellidae) with contrasting hibernation behavior. Eur. J. Entomol. 90: 465-470.

NEDVĚD O. 1998: Modelling the relationship between cold injury and accumulated degree days in terrestrial arthropods. CryoLetters 19: 267-274.

NEDVĚD O. 2000a: Chill tolerance in the tropical beetle Stenotarsus rotundus. Cryo-Letters 21: 25-30.

NEDVĚD O. 2000b: Snow White and the seven dwarfs: a multivariate approach to classification of cold tolerance. CryoLetters 21: 339-0348. 
NedvĚd O., LaVy D. \& Verhoef H.A. 1998: Modelling the timetemperature relationship in cold injury and effect of hightemperature interruptions on survival in a chill-sensitive collembolan. Func. Ecol. 12: 816-824.

O'Doherty R. \& BALE J.S. 1985: Factors affecting coldhardiness of the peach-potato aphid Myzus persicae. Ann. Appl. Biol. 106: 219-228.

Ohyama Y. \& Asahina E. 1972: Frost resistance in adult insects. J. Insect Physiol. 18: 267-282.

OKe T.R. 1987: Boundary Layer Climates. 2nd ed. Methuen, London, $435 \mathrm{pp}$.

Olsen T.M. \& Duman J.G. 1997: Maintenance of the supercooled state in the gut fluid of overwintering pyrochroid beetle larvae, Dendroides canadensis: role of ice nucleators and antifreeze proteins. J. Comp. Physiol. (B) 167: 114-127.

Pantyukhov G.A. 1964: The effect of low temperatures on different populations of the Brown-tail Moth Euproctis chrysorrhoea (L.) and the Gypsy Moth Lymantrria dispar (L.) (Lepidoptera: Orgyidae). Entomol. Rev. 43: 47-65.

Pantyukhov G.A. 1971: Coldhardiness in some species of Coccinellidae. In Maavara V. (ed.): Coldhardiness in Insects and Mites. Abstracts from a Symposium Held in Tartu (Estonian SSR) April 19 to 21, 1971. Academy of Sciences of the Estonian SSR, Tartu, pp. 103-108 (in Russian).

Pullin A.S. \& BALE J.S. 1989: Influence of diapause and temperature on cryoprotectant synthesis and coldhardiness in pupae of Pieris brassicae. Comp. Biochem. Physiol. (A) 94: 499-503.

Pullin A.S., Bale J.S. \& Fontaine X.L.R. 1991: Physiological aspects of diapause and cold tolerance during overwintering in Pieris brassicae. Physiol. Entomol. 16: 447-556.

RamLøv H. 1999: Microclimate and variations in haemolymph composition in the freezing-tolerant New Zealand alpine weta Heimideina maori Hutton (Orthoptera: Stenopelmatidae). $J$. Comp. Physiol. (B) 169: 224-235.

Ramløv H. 2000: Aspects of natural cold tolerance in ectothermic animals. Human Reprod. 15 (Suppl. 5): 26-46.

Renault D., Salin C., Vannier G. \& Vernon P. 2002: Survival at low temperatures in insects: what is the significance of the supercooling point. Cryo-Letters 23: 217-228.

Rickards J., Kelleher R.J. \& Storey K.B. 1987: Strategies of freeze avoidance in larvae of the goldenrod gall moth Epiblemma scudderiana: winter profiles of a natural population. J. Insect Physiol. 33: 443-450.

RING R.A. 1982: Freezing-tolerant insects with low supercooling points. Comp. Biochem. Physiol. (A) 73: 605-612.

Ring R.A. \& TESAR D. 1980: Coldhardiness of the Arctic beetle Pytho americanus Kirby, Coleoptera, Pythidae (Salpingidae). J. Insect Physiol. 26: 763-774.

Roberts S.J., Armbrust E.J. \& Sell D.K. 1972: Supercooling points of several species of Lepidoptera found on soybeans. Envir. Entomol. 1: 671-672.

Sakagami S.F., Tanno K., Tsutsui H. \& Honma K. 1985. The role of cocoons in overwintering of the Soybean Pod Borer Leguminivora glycinivorella (Lepidoptera: Tortricidae). $J$. Kans. Entomol. Soc. 58: 240-247.

SALt R.W. 1959: Role of glycerol in the cold-hardening of Bracon cephi (Gahan). Can. J. Zool. 37: 59-69.

SATVELD O. 1975: Overvintringsbiologien tilden skarptannete barkbillen Ips acuminatus Gyll. (Coleoptera: Scolytidae) med scerlig vekt på kuldetoleranse. University of Oslo, $112 \mathrm{pp}$.

Shel'Deshova G.G. 1967: Ecological factors determining distribution of the Codling Moth Laspeyresia pomonella L. (Lepidoptera, Tortricidae) in the northern and southern hemispheres. Entomol. Rev. 46: 349-360.
Shimada K., Sakagami S.F., Honma K. \& Tsutsui H. 1984: Seasonal changes of glycogen/trehalose contents, supercooling points, and survival rate in mature larvae of the overwintering Soybean Pod Borer Leguminivora glycinivorella. J. Insect Physiol. 30: 369-373.

Shintani Y. \& IshiKaWA Y. 1999. Geographic variation in coldhardiness of eggs and neonate larvae of the yellow-spotted longicorn beetle, Psacothea hilaris. Physiol. Entomol. 24: $158-164$.

SinCLAIR B.J. 1999: Insect cold tolerance: How many kinds of frozen? Eur. J. Entomol. 96: 157-164.

SinCLAIR B.J. 2001: Field ecology of cold tolerance: interannual variation in cooling rates, freeze-thaw and thermal stress in the microhabitat of the alpine cockroach Celatoblatta quinquemaculata. Oikos 93: 286-293.

Sinclair B.J., Addo-Bediako A., Chown S.L. 2003: Climatic variability and the evolution of insect freeze tolerance. Biol. Rev. 78: 181-195.

Sømme L. 1964: Effects of glycerol on cold-hardiness in insects. Can. J. Zool. 42: 87-101.

Søмme L. 1965: Further observations on glycerol and coldhardiness in insects. Can. J. Zool. 43: 765-770.

Søмme L. 1967: The effect of temperature and anoxia on haemolymph composition and supercooling in three overwintering insects. J. Insect Physiol. 13: 805-814.

Søмme L. 1978: Nucleating agents in the haemolymph of third instar larvae of Eurosta solidaginis (Fitch) (Dipt., Tephritidae). Norw. J. Entomol. 25: 187-188.

Søмme L. 1982: Supercooling and winter survival in terrestrial arthropods. Comp. Biochem. Physiol. (A) 73: 519-543.

Søмme L. 1999: The physiology of cold hardiness in terrestrial arthropods. Eur. J. Entomol. 96: 1-10.

Sømme L. \& Zachariassen K.E. 1981: Adaptations to low temperatures in high altitude insects from Mount Kenya. Ecol. Entomol. 6: 199-204.

Storey K.B. \& Storey J.M. 1987. Freeze tolerance: constraining forces, adaptive mechanisms. Can. J. Zool. 66: $1122-1127$.

SulLivan C.R. 1965: Laboratory and field investigations on the ability of eggs of the European pine sawfly, Neodiprion sertifer (Geoffroy) to withstand low temperatures. Can. Entomol. 97: 978-993.

Sullivan C.R. \& Wallace D.R. 1972: The potential northern dispersal of the Gypsy Moth, Porthetria dispar (Lepidoptera: Lymantriidae). Can. Entomol. 104: 1349-1345.

TAuber M.J., TAuber C.A. \& MASAKI S. 1986: Seasonal Adaptations of Insects. Oxford University Press, New York, 411 pp.

Tenow O. \& NiLSSEN A. 1990: Egg cold hardiness and topoclimatic limitations to outbreaks of Epirrita autumnata in northern Fennoscandia. J. Appl. Ecol. 27: 723-734.

Trewartha G.T. \& Horn L.H. 1980: An Introduction to Climate. McGraw-Hill, New York, 416 pp.

Truchan J. \& Butcher J.W. 1970: Coldhardiness of Dendrosoter protuberans. J. Econ. Entomol. 63: 328-330.

Tsutsui H., Tanno K. \& Torikura H. 1987: Coldhardiness of overwintering eggs in Celaena leucostigma and Amphipoea fucosa (Lepidoptera: Noctuidae). Jap. J. Appl. Entomol. Zool. 31: 261-263.

TuRNOCK W.J. 1993: Cold-hardiness of Lacanobia atlantica (Lepidoptera: Noctuidae), and a comparison with three other insect species that overwinter in the same habitat. Can. J. Zool. 71: 1710-1714.

TURNOCK W.J. \& BilodeAu R.J. 1992: Life history and coldhardiness of Athrycia cinerea (Dipt.: Tachinidae) in western Canada. Entomophaga 37: 353-362. 
TURNOCK W.J. \& BoDnaryk R.P. 1991: Latent cold injury and its conditional expression in the Bertha armyworm, Mamestra configurata (Noctuidae: Lepidoptera). Cryo-Letters 12: $377-384$

TURNOCK W.J. \& BoDNARYK R.P. 1993: The reversal of cold injury and its effect on the response to subsequent cold exposures. Cryo-Letters 14: 251-256.

Turnock W.J. \& CARL K.P. 1995: Evaluation of the Palaearctic Eurithia consobrina (Diptera: Tachinidae) as a potential biocontrol agent for Mamestra configurata (Lepidoptera: Noctuidae) in Canada. Biocontrol Sci. Technol. 5: 55-67.

TuRNock W.J., LAMB R.J. \& BodNaRYK R.P. 1983: Effects of cold stress during diapause on the survival and development of Mamestra configurata (Lepidoptera: Noctuidae). Oecologia 56: 185-192.

Turnock W.J., Jones T.H. \& Reader P.M. 1985: Effects of cold stress during diapause on the survival and development of Delia radicum (Diptera; Anthomyiidae) in England. Oecologia 67: 506-510.

Turnock W.J., Reader P.M. \& Bracken G.K. 1990: A comparison of the coldhardiness of populations of Delia radicum (L.) (Diptera: Anthomyiidae) from southern England and the Canadian prairies. Can. J. Zool. 68: 830-835.
TuRnock W.J., BoIvin G. \& Ring R.A. 1998: Interpopulation differences in the coldhardiness of Delia radicum (Diptera: Anthomyiidae). Can. Entomol. 130: 119-129.

VAN DeR LAAK S. 1982: Physiological adaptations to low temperature in freezing-tolerant Phyllodecta laticollis beetles. Comp. Biochem. Physiol. (A) 73: 613-620.

VAN DER Woude \& Verhoef H.A. 1986: A comparative study of winter survival in two temperate Collembola. Ecol. Entomol. 11: $333-340$

Vernon P., Vannier G. \& Luce J.-M. 1996: Découverte de larves tolérantes et intolérantes à la congélation dans une même guilde de Cétoines (Coléoptères) en forêt de Fountainebleau. Écologie 27: 131-142.

WERNER R.A. 1978: Overwinter survival of spear-marked black moth, Pheumaptera hastata (Lepidoptera: Geometridae), pupae in interior Alaska. Can. Entomol. 110: 877-882.

ZACHARIASSEN K.E. 1977: Effects of glycerol in freeze-tolerant Pytho depressus L. (Col., Pythidae). Norw. J. Entomol. 24: 25-29.

ZACHARIASSEN K.E. 1980: The role of polyols and nucleating agents in cold-hardy beetles. J. Comp. Physiol. 140: 227-234.

ZACHARIASSEN K.E. \& HAMMEL H.T. 1976: Nucleating agents in the haemolymph of insects tolerant to freezing. Nature 262: 285-287.

Received February 11, 2005; revised and accepted June 14, 2005 